\title{
Implicitně náboženské aspekty dětské literatury Jaroslava Foglara
}

\author{
IVO JIRÁSEK - JIŘí NĚMEC - RICHARD MACKU゚
}

\section{Ryze sekulární literatura pro chlapce}

Málokterý český spisovatel věnující se literatuře pro děti se u nás těší tak dlouhodobé a mimořádně silné čtenářské oblibě jako Jaroslav Foglar (1907-1999). Bez ohledu na časové určení, kdy byly jeho texty psány a vydávány (od roku 1934 do současnosti), a navzdory dlouhým obdobím, kdy jeho knihy nejenom nebyly vydávány, ale dokonce byly odstraňovány z veřejných knihoven (od padesátých let do poloviny let šedesátých a následně od začátku sedmdesátých let do druhé poloviny let osmdesátých), je překvapivě konstantní a vysoká znalost jeho díla, mimořádně populárního u čtenářské obce, nejenom mezi dětmi a mládeží. Průzkumy čtenářské obliby realizoval mimo jiné časopis Vpřed v roce 1947, Památník národního písemnictví v roce 1957, časopis Zlatý máj v roce 1964, časopis Mladý $s v e ̌ t ~ v$ roce 1988 , veřejné knihovny na počátku devadesátých let či celostátní anketa Moje kniha v roce 2004. ${ }^{1}$ Jaroslav Foglar se vždy umistuje na předních místech hlasování, znalost jeho díla jde napřič generacemi, obliba se neliší u chlapců a dívek, opakovaně je potvrzováno př́iznivé ovlivnění čtenářů jednáním literárních hrdinů.

Jaroslav Foglar byl nejenom spisovatelem románů, povídek a dalších literárních žánrů, ale také redaktorem několika časopisů, autorem scénářů kreslených seriálů, výrazným vychovatelem, který celý život zasvětil

1 Bohumil Jírek, „Počítejme s Foglarem“, Zlatý máj 8/11, 1964, 504-507; Roman Lipčík, „Řekni mi, co čteš...“, Mladý svět 30/16, 1988, 6-7; Jiří Mrva, Jaroslav Foglar, Kroměříž: Okresní knihovna 1990; Zdeněk Pírek, Čtenářské kluby Jaroslava Foglara, Brno: Delfín 1990; Vít Richter - Zlata Houšková, „Nejoblíbenější kniha obyvatel České republiky“ [online], <http://www.mojekniha.cz/>, [6. 8. 2020]; Stanislav Sohr, Zase zní Píseñ úplňku: Vyprávění o Jaroslavu Foglarovi, Ostrava: Puls 1968; Daniela Uherková - Helena Úlovcová, „Co se čte ve veřejných knihovnách“, Čtenář: Měsíčník pro práci s knihou 45/9, 1993, 282-293; Svatava Urbanová - Blanka Matýsková, Jaroslav Foglar, (Tematická jednotka pro základní školy), Ostrava: Item 1992. 
rozvoji a propagaci skautingu. V podstatě lze shrnout, že výchovným snahám byla podřízena nejenom jeho činnost skautského vůdce (šedesát let nepřetržitého vedení pražského oddílu), ale rovněž jeho psaná tvorba, takže je možno jeho dílo vnímat nejenom optikou literární kritiky jako beletrii, ale spíše pedagogickým úhlem pohledu jako výchovné příručky. Tudíž děj, příběh, popisy scenérie a činnost postav jsou pouhým prostředkem, nástrojem edukativních cílů, jež mají napomáhat proměně čtenářovy osobnosti.

K seznámení s tímto širokým fenoménem existuje rozsáhlá literatura. V edici Sebrané spisy Jaroslava Foglara nakladatelství Olympia bylo v letech 1991-2018 vydáno 27 svazků (kromě románů, povídek, instruktivních příruček rovněž jeho autobiografie, výpisky z kronik a soubor her), navíc také výpravné vydání komiksů. ${ }^{2} \mathrm{~V}$ současné době opětovně vychází souhrnné dílo v nové úpravě v nakladatelství Albatros. Sekundární literatura už je takřka nepřehledná. ${ }^{3}$

Hlavními hrdiny Foglarových příběhů jsou chlapci na prahu dospívání, procházející osobnostní proměnou pod vlivem pozitivního příkladu přátelství a aktivního životního stylu. Chlapectví není pouhým úsekem životního běhu, není ohraničeno několika málo roky umístěnými na konci školní docházky a předcházejícími erotickému vzplanutí. Je to svébytná kvalita, o níž je nutno usilovat, ojedinělý svět nezatížený životní empirií, ${ }^{4}$ ideál a symbol tajuplných tužeb, romantiky, výprav, her a soutěží. Foglarovky jsou tak eposem nepromarněného, stoprocentního chlapectví, ${ }^{5}$ ideálem vzorného hocha, jímž se může stát každý, byt je zprvu obyčejným chlapcem prožívajícím zcela všední šedivé dny. Pravděpodobně to, že autor textů sám toužil zůstat věčně chlapcem ${ }^{6}$ a až rozjitřeně rozuměl prchavým okamžikům a potřebám dospívajících, mu umožnilo ,,psát tak, jak by psal třináctiletý kluk, kdyby uměl psát"“?

Mezi hlavní hodnoty, které autor svým dílem i výchovnou praxí propagoval, patří:

2 Jaroslav Foglar, Rychlé šipy, Praha: Olympia ${ }^{2} 2003$; id., Svorni Gambusíni a jiné př́běhy, Praha: Olympia 2003.

3 Kromě odkazů zmiňovaných v jiných souvislostech tohoto příspěvku si pozornost hlubších zájemců zaslouží zejména tyto shrnující tituly: Ivo Jirásek (ed.), Fenomén Foglar, Praha: Prázdninová škola Lipnice 2007; Václav Nosek-Windy, Jestřábí perutě: Povídání o foglarovkách, Praha: Olympia 1999; Zdeněk Pírek, Čtenářské kluby...; Jiří Zachariáš, Stoletý hoch od Bobři řeky, Praha: Ostrov 2007; Miloš Zapletal, Záhady a tajemství Jaroslava Foglara, Praha: Euromedia Group - Knižní klub 2007.

4 Vojtěch Vacke, ,Svět pouze pro chlapce?“", Kmen 1/40, 1988, 1 a 3.

5 Petr Sadecký, „Proč mlčí Jaroslav Foglar?“, Zlatý máj 8/3, 1964, 105-108.

6 Jaroslav Foglar, Život v poklusu, Praha: Olympia 2005, 7.

7 Jan Halas, ,...od plantážníka ze všech plantážníků nejplantážníkovatějšího....", in: Jindřich Hojer - Václav Černý (eds.), Jestřábe, diky: Jaroslavu Foglarovi Hoši od Bobři řeky a přátelé, Praha: Nakladatelství Ostrov 2000, 124-127: 127. 
- zdravý způsob života, dostatek pohybové aktivity podporující fyzickou zdatnost a otužilost, absence kouření a alkoholu;

- zájem o přírodu, vyjevovaný až pateticky barevnými popisy přírodnin, okouzlení krásou celku scenérie i detailů tvarů a barev;

- čestnost v jednání, vyjevovaná slušnou mluvou, nutností odlišovat dobro od zla, nabádáním k čestnému životu, pravdomluvnosti a cti;

- kolektivita party (oddíl, školní třída, neformální kolektiv v místě bydliště, klub) a aktivizace vrstevnického společenství, důvěra v samostatnost;

- celostní působení, holistický rozvoj osobnosti v dimenzi fyzické, psychické, mravní, rukodělné i estetické (prostřednictvím konkrétních metod jako „lov 13 bobříků“, „modrý život“ aj.). ${ }^{8}$

Témata, která se na první pohled míjejí se zájmem religionistického bádání. Proč je tedy přenášíme na stránky tohoto časopisu? Protože v poslední době se hodnocení osoby a díla Jaroslava Foglara chopila nejenom literární kritika a pedagogika, ale také komiksová studia a - což je pro tento prŕspěvek podstatné - religionistika.

\section{Religionistický zájem o foglarovský svět}

Sekundární literatura a kritika zabývající se tímto specificky českým fenoménem již opakovaně využila religionistických pojmů a postupů k popisu působení Foglarových textů. Celý tento paralelní svět, svět opozice dobra a zla, byl označen jako „,svět mýtu“,9 či dokonce jako „symbolické univerzum“ zasahující „úroveň nejhlubších existenciálních otázek“, takže se stává „symbolickým systémem nejvyšší významnosti“" neboli „funkčním ekvivalentem náboženství“. ${ }^{10} \mathrm{Na}$ potenciálně náboženský rozměr tohoto svébytného světa však bylo v poslední době upozorňováno opakovaně, např́iklad při analýze vzorů, podkladů, motivů či prvků, které mohly sloužit jako podloží pro Foglarovy příběhy, a současně při zevrubné analýze ohlasů a odezev, které toto dílo vyvolalo v sociální realitě. ${ }^{11}$ Nebo v rámci literárněvědné analýzy paralel $\mathrm{k}$ iniciačním cestám a rituálním zkouškám, k mýtu, mytickému prostoru a mytické zkušenosti, $\mathrm{k}$ archetypům

8 Ivo Jirásek, „Prototyp zážitkového pedagoga“, in: Ivo Jirásek (ed.), Fenomén Foglar, Praha: Prázdninová škola Lipnice 2007, 25-83.

9 Vladimír Nezkusil, „Rozpory Foglarova světa: K prvnímu soubornému vydání ,stínadelských“ př́běhů“, Zlatý máj 35/3, 1991, 157-163: 162.

10 Pavel Hošek, Evangelium podle Jaroslava Foglara, Brno: Centrum pro studium demokracie a kultury 2017, 42 a 55.

11 Miloš Dvorský, Mýtus zvaný Stínadla: Rychlé šípy, Vontové a hlavolam: Realita versus fikce, Praha: Zdeněk Bauer ${ }^{2} 2011$. 
ráje (v popisovaných krajinách) a labyrintu (v městském prostř̌edí), kdy je Píseň úplňku v autorově interpretaci modlitbou, ježek v kleci sakrálním předmětem a tajemství a rituál vyjmutí hvězdice $\mathrm{z}$ hlavolamu se rovná extatickému zjevení. ${ }^{12}$ Cíleně a záměrně byly náboženské aspekty Foglarovy literatury i širšího fenoménu foglaringu coby životní praxe testovány na komplexním výkladovém modelu sedmi dimenzí náboženského vztahu ke skutečnosti (svaté obřady, svaté nauky, svaté příběhy, svaté prožitky, svatá přikázání, svaté společenství a svaté předměty) s potvrzením náboženské funkčnosti, navíc v komparaci s Lewisovým pojetím proměňujících účinků četby a Tolkienovou teorií pohádkových př́iběhů. ${ }^{13}$

Jak je to možné? Explicitně religiózní podání je Foglarovým příběhům zcela evidentně cizí. Jedná se o ryze sekulární příběhy, v nichž jakoukoliv přímou zmínku týkající se náboženských fenoménů můžeme nalézt jen velmi sporadicky, například u talismanu Bratrstva kočičí pracky, v čarodějnictví a kouzlech staré Jeremiášky, což jsou momenty, které spíše zprostředkovaně vedou $\mathrm{k}$ tematice pověr, proti nimž hlavní hrdinové (klub Rychlých šípů) bojují a proti nimž vystupoval a jimž se trvale vysmíval i Jaroslav Foglar. Druhým rozměrem by mohly být křestanské svátky (Mikuláš, Vánoce, Tři králové, svatodušní svátky), ovšem v př́ibězích jsou bez jakékoliv charakteristiky svátků náboženských, jsou spíše slavnostmi naplněnými lidovými zvyky a dáváním dárků, respektive pouhými dny volna. Poslední zmínku by si zasloužila sakrální architektura, která vystupuje v nezřetelném pozadí starého města, nicméně katolický kostel hraje hlavně roli prostoru a scenérie, v níž se odehrává mysteriózní příběh spojený s hlavolamem ježka v kleci14 ${ }^{14}$ ani zde však není spojitost s náboženskými aktivitami a kontexty přímá.

Absence explicitně náboženské dimenze př́iběhů je zcela pochopitelná $\mathrm{s}$ ohledem na to, že autor těchto textů byl osobně k náboženství zcela chladný. Křtem sice konfesně přináležel k římskému katolicismu, avšak rozhodnutím matky byl již v raném dětství odhlášen z církve. Celý život se neúčastnil náboženského života, religiózním ideám byl naprosto nepř́istupný. Za své náboženství a náboženské přesvědčení výslovně označil výchovu mládeže a skauting. ${ }^{15}$ Přesto se při hodnocení Foglarových světských příběhů používají termíny jako „božstvo“ a „zbožštění“, „kult“, „mystérium“, „skautské evangelium“, „,evangelizační text“, „posvátná

12 Tomáš Vučka, Cesta za modrým světlem: Meditace nad texty Jaroslava Foglara, Př́ibram: Pistorius a Olšanská 2015.

13 P. Hošek, Evangelium podle Jaroslava Foglara...

14 Jaroslav Foglar, Záhada hlavolamu, Praha: Olympia 1997; id., Stínadla se bouř́, Praha: Olympia 2005; id., Tajemství Velkého Vonta, Praha: Olympia 2005.

15 Jaroslav Foglar, Jestř́ábe, vypravuj..., Praha: Olympia 1998, 84. 
úcta“, „modlitba“, „sakrální předmět“, „rituál“, „iniciační zasvěcení“, „mystický zážitek“ či „zjevení tajemství“. 16

\section{Implicitně náboženský rozměr foglarovek}

Předběžně konstatujme, že implicitně náboženskou dimenzi Foglarova díla neshledáváme v tématu vystupujícím evidentně do popředí (volnočasová aktivita dětského kolektivu), ale spíše v jeho jedinečném zvýznamnění romantiky, tajemství a tajuplnosti, která je zvyšována specifickou obřadností rituálů a budování tradice. Jedná se spíše o př́istupy či prostř̌edky, jež Foglar využívá k popisům př́írody, osobní cti či prožívaného společenství. Jeho popisy romantických zákoutí městských uliček a dvorků, stejně jako přírodních krajin tak probouzí ve čtenářích nejen estetické prožitky, ale rovněž cit pro odhalování atmosférotvorného tajemna. Tajuplné legendy dodávají atraktivitu příběhům nejenom v rozměru aktivity, ale také jedinečné narativity tajemství, jež je třeba odhalovat. Napínavé př́iběhy vedou často i k tematice smrti a tragična, která napomáhá jistému rozměru transcendence. Důležitým se stává nejenom slovo a informace, kterou nese, ale také mlčení zvyšující zájem. Nevyřčené dodává prostor dohadům a tajuplná romantika vyzývá k odhalení. Rituálem a obřadem se stává jakákoliv činnost pravidelně opakovaná, jednoduchý předmět získává ustáleným způsobem využívání zajímavost aureoly či tabu. Pečlivě, či až úzkostlivě dodržované tradice dodávají př́iběhům i aktivitám punc svátečnosti. Foglar tak zapojuje jednotlivé obsahy i formy sdělení do svébytného systému, jehož prostřednictvím dokáže uspokojit spirituální potř̌eby včetně vzorů hodných napodobení, kodexů i omezení usměrňujících jednání.

Nejenom k hodnocení textů samotných, ale také společenství „foglarovců“, tedy hlubších zájemců o Foglarovo dílo a jeho působení, byla již religionistická terminologie využita (byt toto užití postrádá ucelený kontext; metafora má sloužit ke kritice adorativních apologetů nepřijímajících kritické argumenty): „Foglar a jeho svět tak vyvstává jako fenomén nepochybně primárně náboženský, byt se takto nedeklaruje. Dokud se takovéto společenství jako primárně náboženské samo nepochopí, nesmí se divit, když jsou na jeho zakladatele a svaté knihy aplikována ryze světská měřítka." ${ }^{\prime 17}$

Takto silné hodnocení se pro nás stává výzvou: opravdu si foglarovské společenství zasluhuje takové označení? Pro society či společenská hnutí, která sama sebe nechápou jako náboženská, avšak je možné je tak

16 Viz odkazy 9-12.

17 Stanislav Komárek, „Fetvy“, Salon: Literární príloha Práva 232, 2001, 2. 
analyzovat prostřednictvím jejich projevů, se vžil termín ,implicitní náboženství“ ${ }^{18}$ Přestože je toto pojetí českými sociology náboženství přejímáno ${ }^{19}$ a aplikováno na rozmanité fenomény sociálního života, včetně folkové hudby, ${ }^{20}$ existuje také odlišné využití stejného jazykového výrazu, které chápe implicitní náboženství jako konstitutivní rys lidství a považuje za prospěšnou otázku, zda sekulární (světský) život obsahuje sobě vlastní náboženské atributy. ${ }^{21} \mathrm{Na}$ rozdíl od předchozího pojetí, které zůstává v rovině antropologické a sociologické, můžeme v tomto odlišném rámci vnímat i jisté ontologické souvislosti (odlišnost sakrálního a profánního). Tento přistup však v českém prostředí doposud nebyl systematicky reflektován kromě obsáhlého pojednání představujícího nejenom koncept samotný, ale také jeho využití právě při analýze foglaringu na příkladu komiksu Rychlé šípy. ${ }^{22}$

Základní rysy Waardenburgova pojetí jsou relativně jednoduché: zatímco explicitní náboženství se identifikují jako náboženství a prezentují se tak, implicitní (nevědomá, nepřímá) náboženství se za náboženství nepovažují, naopak takové sebeurčení přímo odmítají. Pak nezbývá než analyzovat jako náboženské jejich vnější projevy, například rituály sociálně-politických systémů nacionálního socialismu či marxismu-leninismu. Jejich funkce tak může být shledána jako náboženská, včetně legitimizace sociální struktury a řádu. ${ }^{23}$ Do stejné kategorie úvah lze zařadit rovněž termíny „,politické náboženstvi““, „civilní náboženství“ či „občanské náboženství“. ${ }^{24}$ Podstatné rysy takto chápaných ,implicitních náboženství“ v podobě různorodých společenských uskupení jsou shledávány v sociálním rozměru a sociální funkci působení, ve vybraných paralelách mezi explicitními náboženstvími a sekulárními societami. Podstatnější pro naše

18 Jacques Waardenburg, Bohové zblizka: Systematický úvod do religionistiky, trans. Dalibor Antalík, Brno: Masarykova univerzita 1997, 123-130.

19 Zdeněk R. Nešpor - Dušan Lužný, Sociologie náboženství, Praha: Portál 2007.

20 Zdeněk R. Nešpor, „Česká folková hudba 60.-80. let 20. století v pohledu sociologie náboženství“, Sociologický časopis / Czech Sociological Review 39/1, 2003, 79-97.

21 Edward Bailey, The Secular Faith Controversy: Religion in Three Dimensions, London: Continuum 2001; id., ,The Notion of Implicit Religion: What It Means, and Does Not Mean“, in: Edward Bailey (ed.), The Secular Quest for Meaning in Life: Denton Papers in Implicit Religion, Lewiston: Edwin Mellen Press 2002, 1-11; id., „Implicit Religion“, Religion 40/4, 2010, 271-278; id., „The Concept of Implicit Religion: What, When, How, and Why?“, in: Patrick Michel - Enzo Pace (eds.), Annual Review of the Sociology of Religion II: Religion and Politics, Leiden: E. J. Brill 2011, 309-325; id., ,,Implicit Religion?“ What Might That Be?“, Implicit Religion 15/2, 2012, 195-207.

22 Ivo Jirásek, „Rychlé šípy, ,mundus imaginalis“ a implicitní náboženství“, in: Pavel Hošek (ed.), Duchovní rozměr fenoménu Foglar, Praha: Dingir 2018, 143-197.

23 J. Waardenburg, Bohové zblizka..., 128.

24 Ibid., 127. 
souvislosti je však alternativní pojetí implicitního náboženství, jež Bailey nestaví na protikladu $\mathrm{k}$ explicitním náboženstvím, neuvažuje tedy různá implicitní náboženství v plurálu, ale vymezuje jeho podstatu ve třech základních rysech: 1) commitment(s) neboli závazky či povinnosti, spektrum lidské intencionality na všech úrovních vědomých i nevědomých psychických dimenzí; 2) integrating foci čili integrující ložiska či zaměřující ohniska jakožto element integrující individuální a skupinový život od malých skupin po anonymní davy; 3) intensive concerns with extensive effects, intenzivní zájmy s rozsáhlými účinky, prvek holistického fungování, umožňující spojení mezi posvátným a světským (profánním). ${ }^{25}$ Bailey předpokládá takové potenciální propojení stále, navíc jako platné pro kohokoliv bez ohledu na jeho/její náboženské zakotvení, nebot náboženské a světské nevnímá jako opozita, ale jako dvě strany téže mince, jako komplementaritu. Implicitní náboženství identifikuje jako jejich střed, třetí element, pro nějž vyhrazuje pojem ,sekulárni““ (obvykle synonymum profánního). Namísto protikladů posvátného a profánního nabízí kontinuum sakrální - sekulární (základna implicitního náboženství) - světské, s možností přechodu mezi těmito sférami kýmkoliv bez ohledu na náboženské přesvědčení. ${ }^{26}$ Implicitní náboženství je tak jakousi antropologickou konstantou, neutrálním rysem lidského způsobu bytí, stejně jako tělesnost nebo sexualita. To Baileymu také umožňuje (na rozdíl od Waardenburga) uvažovat o kterémkoliv explicitním náboženství jako o korektním vyjádření implicitního náboženství, nebở religiozita je v implicitní podobě platná pro kohokoliv, ateisty nevyjímaje. Je to nejhlubší a neuvědomovaná součást lidské identity. ${ }^{27}$ Zdá se, že takové vymezení implicitního náboženství bychom mohli spíše než ve vazbě na občanské či civilní náboŽenství vnímat prostřednictvím termínu spiritualita, pokud bychom akceptovali ducha jako konstitutivní rys lidského života, např́iklad v pojetí filozofické antropologie Maxe Schelera. ${ }^{28}$

Rádi bychom podrobili hypotézu o implicitně náboženském rozměru Foglarových textů, jejich recipientů i širšího foglarovského společenství empirickému testu a ověřili, zda je oprávněné takový kontext používat. Zajímá nás tedy, zda se čtenáři těchto chlapeckých příběhů rekrutují z explicitně náboženského, spirituálního, či indiferentního prostředí, jestli si uvědomují určitou duchovní složku této dětské literatury, př́ípadně zda ji vnímají jako cestu k realizaci prožitků, jež můžeme chápat jako spirituální. Jinými slovy, úžeji spojenými s Baileyho konceptem implicitního náboženství, ptáme se, zda můžeme foglarovky a foglaring vnímat jako

25 E. Bailey, ,The Notion of Implicit Religion...“, 4.

26 Ibid., 4-6.

27 Ibid., 9.

28 Max Scheler, Místo člověka v kosmu, Praha: Academia 1968. 
implicitní náboženství, tedy jako potenciální most mezi posvátným a profánním, jako vyjádření spirituální složky života. Tím se snažíme rozšířit a obohatit dosavadní diskuse týkající se díla J. Foglara vedené v diskursu religionistiky.

\section{Empirické šetření}

Vlastní šetření bylo součástí rozsáhlejšího dotazníkového výzkumu, který byl realizován v květnu až červenci roku 2020 a byl zacílen na mapování významu díla Jaroslava Foglara v kontextu jeho dopadu na osobnostní změnu a každodenní život respondentů. Dílo Jaroslava Foglara jsme definovali šířeji jako znalost nebo osobní zkušenost žitou prostřednictvím beletrie, kreslených komiksových příběhů, filmů, divadelních představení, táborových her či členství v oddíle, osobních setkání apod. Rovněž míra intenzity deklarovaného zájmu byla předmětem dotazování, aby mohla být součástí analýzy a mohla být dána do vztahu k dalším proměnným.

\subsection{Výzkumný soubor}

Výzkumný soubor proto nebyl tvořen prostřednictvím náhodného výbě$\mathrm{ru}$, ale vzhledem k deklarovanému záměru jsme cíleně oslovovali prostřednictvím vysvětlujícího a motivačního dopisu potenciální respondenty, kteří měli nebo mohli mít zkušenost s dílem Jaroslava Foglara. Osloveni byli zejména členové zájmových a dětských organizací, které obsahově i ideově čerpají z autorova díla (Sdružení přátel Jaroslava Foglara, Junák - český skaut, Pionýr, Česká tábornická unie ad.), dále byly informace předány provozovatelům webových stránek specializovaných na foglarovskou tematiku (bohousek.cz, foglarovec.cz, iklubovna.cz aj.) i dalším potenciálním zájemcům (zástupci Kruhu přátel odkazu Jaroslava Foglara, autoři textů publikující v dané oblasti či další foglarovci, na něž jsme získali př́imý kontakt). Adresáti takto vytvořených mailing listů byli vyzváni, aby zprávu šířili dále ve svém okolí, vytvořena byla rovněž specializovaná facebooková událost. Prostřednictvím takto modifikované metody „,sněhové koule“ jsme získali 1135 plnohodnotně vyplněných dotazníků, ve kterých bylo zastoupeno 666 mužů a 464 žen s následujícími charakteristikami. S ohledem na místo bydliště tvořili nejpočetnější kategorii respondenti z měst nad 100 tis. obyvatel - 554, tj. $49 \%$. Průměrný věk respondentů byl 41 let. Největší věkovou skupinou zastoupenou v souboru byli respondenti ve věku 30-55 let, kteří tvořili 57 \% všech dotazovaných (viz obr. 1). 


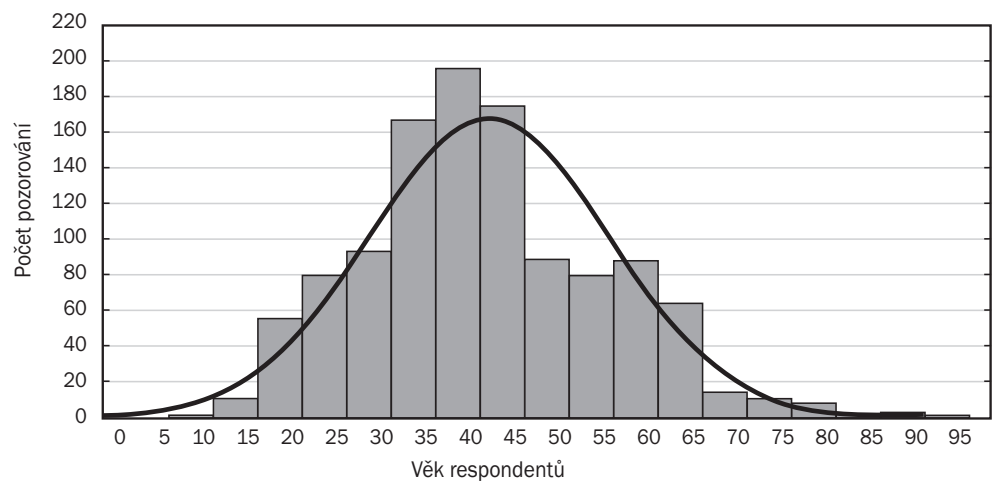

Obr. 1. Histogram - rozložení věkového zastoupení respondentů.

V našem vzorku převažovali respondenti s vysokoškolským vzděláním (684, tj. 60 \%). Přičteme-li k této skupině i respondenty s postgraduálním vzděláním nebo ty, kteří se na něj připravují, dostáváme se k hranici $75 \%$. Ve výběrovém souboru, který je charakteristický zájmem o dílo J. Foglara, jednoznačně převažuji respondenti s vysokoškolským vzděláním a vědeckou př́ipravou, nezanedbatelnou skupinou jsou respondenti, kteří ukončili střední odbornou školu s maturitou nebo jsou absolventy vyšší odborné školy $(21 \%)$. Zcela marginální je pak skupina se základním vzděláním (1\%) a vyučených nebo absolventů střední odborné školy bez maturity (4\%). Za zmínku ještě stojí fakt, že naprostá většina respondentů se seznámila s dílem J. Foglara v dětství, do 12 let věku (85,4 \%), respektive do 17 let $(12,6 \%)$, a takřka zanedbatelná menšina (1,9 \%) až v dospělosti.

\subsection{Metodologie}

Teoretická východiska a koncepty popsané výše jsme operacionalizovali do dílčích položek dotazníkového (elektronického) šetření. Data měla charakter zpravidla nominálních proměnných, popřípadě proměnných ordinálních (sedmibodové škálové položky), zejména když jsme zjištovali intenzitu vztahu, míru identifikace nebo sílu souhlasu s výrokem dané položky. Takto získaná data jsme interpretovali na deskriptivní úrovni a hledali jsme souvislosti mezi jednotlivými kategoriálními, popř́ípadě ordinálními typy proměnných prostřednictvím adekvátních statistických komparací a testů. 


\subsection{Výsledky}

Získaná zjištění členíme a interpretujeme podle předem stanovených výzkumných otázek do čtyř obsahových celků.

a) Z jakého prostředí s ohledem na religiozitu se rekrutují čtenáři díla Jaroslava Foglara (respondenti výzkumu)?

$\mathrm{V}$ kontextu tohoto př́spěvku považujeme za důležité charakterizovat též vztah respondentů k tématům vyjadřujícím jejich náboženský život. Jak je patrné z tabulky 1, mezi respondenty jsou zastoupeni lidé reprezentující celou škálu postojů $\mathrm{k}$ víre, náboženství, transcendentnu apod. Nejméně zastoupeni jsou agnostici (5,8\% všech respondentů), přičemž volba této možnosti byla v dotazníku opatřena vysvětlující tezí, že „boha nelze poznat“. Poměrně vyrovnaně byli v našem vzorku zastoupeni ateisté, tj. bezvěrci, ti, kteři existenci boha odmítají (20,3\%), respondenti s individualizovanou vírou, tj. bez vazby na církve nebo sekty (24\%), a praktikující věřící, kteří se hlásí k registrovaným církvím či definovaným náboženstvím (21,3\%). Volba „spiritualita“ s vysvětlením, že jde o duchovní pohled na život a svět, byla využita v $15,9 \%$ všech odpovědí. Zbytek respondentů, tj. 12,5\%, nemá ohledně víry ujasněný názor.

\begin{tabular}{|c|c|c|c|c|c|c|c|c|}
\hline & \multirow{2}{*}{$\begin{array}{l}\text { Jaký je Váš vztah } \\
\text { k víre, transcendent- } \\
\text { nu apod.? }\end{array}$} & \multicolumn{6}{|c|}{ Věk } & \multirow{2}{*}{$\begin{array}{l}\text { Řádk. } \\
\text { souč- } \\
\text { ty }\end{array}$} \\
\hline & & do 25 & $26-35$ & $36-45$ & $46-55$ & $56-65$ & $\begin{array}{c}66 \\
\text { a více }\end{array}$ & \\
\hline Četnost & Ateismus & 27 & 54 & 81 & 32 & 31 & 6 & 231 \\
\hline Sloup. četn. & & $18 \%$ & $21 \%$ & $22 \%$ & $19 \%$ & $21 \%$ & $16 \%$ & \\
\hline Četnost & Agnosticismus & 3 & 22 & 23 & 10 & 6 & 2 & 66 \\
\hline Sloup. četn. & & $2 \%$ & $8 \%$ & $6 \%$ & $6 \%$ & $4 \%$ & $5 \%$ & \\
\hline Četnost & Spiritualita & 21 & 42 & 61 & 25 & 23 & 8 & 180 \\
\hline Sloup. četn. & & $14 \%$ & $16 \%$ & $17 \%$ & $15 \%$ & $15 \%$ & $21 \%$ & \\
\hline Četnost & Individualizovaná víra & 29 & 62 & 85 & 42 & 43 & 12 & 273 \\
\hline Sloup. četn. & & $20 \%$ & $24 \%$ & $23 \%$ & $25 \%$ & $28 \%$ & $32 \%$ & \\
\hline Četnost & Praktikující věřící & 40 & 50 & 71 & 41 & 34 & 5 & 241 \\
\hline Sloup. četn. & & $27 \%$ & $19 \%$ & $19 \%$ & $24 \%$ & $23 \%$ & $13 \%$ & \\
\hline Četnost & $\begin{array}{l}\text { Neujasněný názor } \\
\text { ohledně víry }\end{array}$ & 27 & 29 & 48 & 19 & 14 & 5 & 142 \\
\hline Sloup. četn. & & $18 \%$ & $11 \%$ & $13 \%$ & $11 \%$ & $9 \%$ & $13 \%$ & \\
\hline Četnost & Všechny skupiny & 147 & 259 & 369 & 169 & 151 & 38 & 1133 \\
\hline
\end{tabular}

Tab. 1. Vztah respondentů k víre a transcendentnu dle věkových kategorií. 
Na tomto místě ještě doplňme, že struktura odpovědí se neliší mezi muži a ženami a statisticky významný rozdíl v rozložení jednotlivých postojů $\mathrm{k}$ víře a transcendentnu jsme nezaznamenali ani $\mathrm{v}$ rámci jednotlivých věkových kategorií.

b) Vnímali respondenti dílo Jaroslava Foglara též jako určitou duchovní inspiraci?

Ze sloupcového grafu (obr. 2) je patrné rozložení odpovědí jednotlivých kategorií na otázku, zda respondenti vnímali dílo J. Foglara jako duchovní inspiraci, na škále od „rozhodně ne“ $(-3)$ po „rozhodně ano“ (+3).

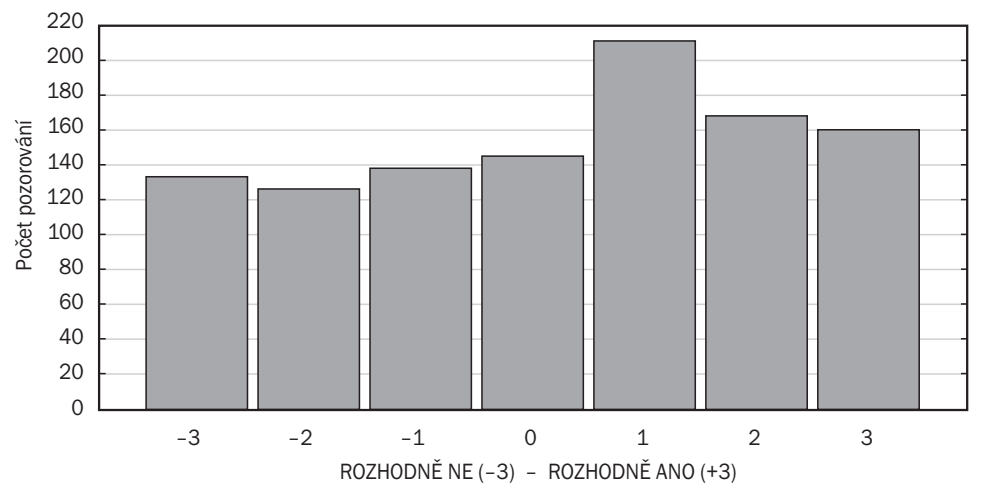

Obr. 2. Histogram - duchovní inspirace dílem J. Foglara.

$\mathrm{Z}$ uvedeného je patrné, že respondenti v položce duchovní inspirace odpovídali v celém možném spektru a všechny kategorie jsou dostatečně obsazeny. Sedmibodovou škálu jsme zvolili zejména s ohledem na skutečnost, aby respondenti mohli volit neutrální postoj (0). Odpovědi od jedné do tří svědčí spíše pro ovlivnění v duchovní oblasti. Zhruba $48 \%$ respondentů tedy vnímalo dílo J. Foglara jako duchovní inspiraci, $35 \%$ spíše tuto oblast daným způsobem nereflektovalo a přibližně $13 \%$ respondentů bylo $\mathrm{v}$ této volbě neutrální. S ohledem na již dříve uvedené tedy můžeme konstatovat relativně překvapující informaci, že čtenáři převážně vnímají dílo J. Foglara jako duchovní inspiraci. Nabízí se otázka, zda na tuto skutečnost má vliv rovněž jejich vztah $\mathrm{k}$ víře či transcendentnu.

Na tuto otázku jsme hledali odpověd prostřednictvím další analýzy dat a vzhledem $\mathrm{k}$ rozsahu vzorku jsme zvolili neparametrický Kruskal-Wallisův test. Vycházeli jsme z testu nulové hypotézy H0, že medián zastoupení odpovědí respondentů na škále se v kontextu jejich vztahu k víre a transcendentnu nemění, tedy je shodný mezi všemi skupinami. 


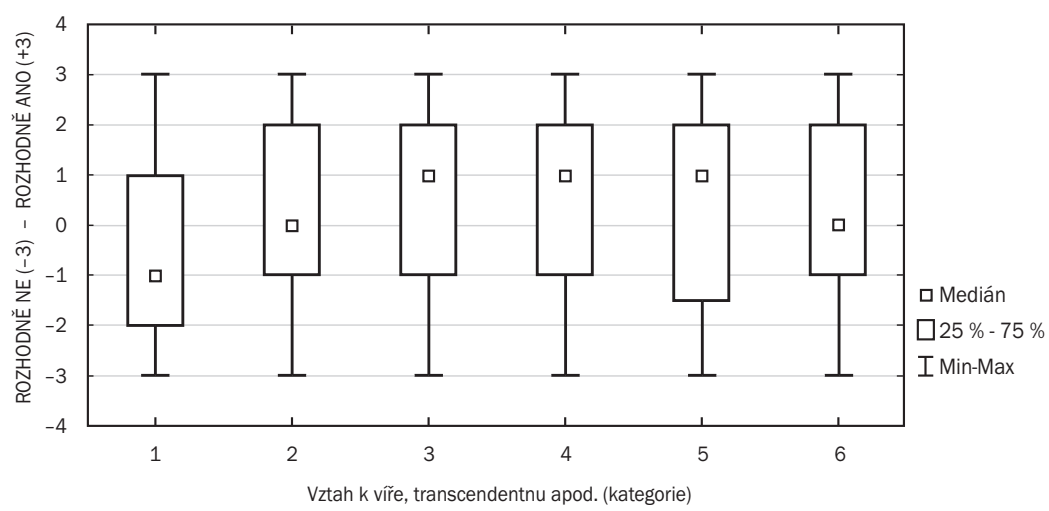

Obr. 3. Krabicový graf dle skupin respondentů a jejich vztahu k víře - duchovní inspirace dílem J. Foglara.

Legenda ke kategoriím 1-6:

1 - ateismus (bezvěrectví, odmitání boha);

2 - agnosticismus (boha nelze poznat);

3 - spiritualita (duchovní pohled na život a svět);

4 - individualizovaná víra (bez vazby na církve a sekty);

5 - praktikujici věřici (hlásíci se k definovaným náboženstvím/církvím);

$6-v$ otázce náboženství nemám ujasněný názor.

Krabicový graf (obr. 3) přináší k této otázce poměrně zajímavé odpovědi. Ukazuje př́slušnost $\mathrm{k}$ jedné ze zvolených kategorií (1-6), vyjadřující volbu deklarované religiozity, a prostřednictvím míry centrální tendence (mediánu) odpovědí na škále a jejich rozptylu vnímání díla J. Foglara jako duchovní inspirace. Vzhledem k povaze ordinálních dat jsme použili mediánové porovnání. Nejmenší duchovní význam má dílo J. Foglara pro ateisty, větší pro agnostiky a ty, kteří v otázce náboženství nemají ujasněný názor, a největší pro respondenty se spirituální orientací, individualizovanou vírou a praktikující věřící. Kruskal-Wallisův test byl významný na hranici významnosti $\mathrm{p}=0,05$, a tudíž můžeme zamítnout nulovou hypotézu ve prospěch alternativní. Př́slušenství respondentů k určité kategorii religiozity má následně vztah k tomu, jak dílo J. Foglara vnímají a zda si z něj odnášejí duchovní inspiraci. Analogických výsledků jsme dosáhli i při použití jiných zobrazení a testů, zejména ANOVA testu (analýzy rozptylu) a Wilcoxonova dvouvýběrového testu. Za použití stejných statistických testů jsme rovněž zjistili významné rozdíly $\mathrm{v}$ odpovědích mužů a žen. Muži vnímají dílo jako duchovní inspiraci ve větší míře než ženy. Z hlediska věku mají větší tendenci vnímat dílo J. Foglara jako spirituální inspiraci zejména respondenti ve věku 46-65 let. 
Je také zajímavé povšimnout si statisticky významného rozdílu v hodnocení této otázky těmi respondenty, kteří se s dílem J. Foglara seznámili skrze obrazy, kresby, komiksy, popřípadě jiné obrazové zpracování. Ti vnímali Foglarovo dílo jako významně méně inspirující v oblasti spirituality než respondenti z ostatních kategorií, tj. ti, kteří dílo poznali prostřednictvím jakéhokoliv literárního zpracování (včetně odborné literatury a metodických textů), dramatického umění nebo např́iklad prostřednictvím přímé zkušenosti s osobností J. Foglara. Zda můžeme přisuzovat tuto menší inspirativnost obrazu oproti větší inspirativnosti slova výše zmíněné narativitě tajemství a tajuplnosti, vhodněji sdílené prostřednictvím verbální deskripce než relativně statickou kresbou, však musíme ponechat bez odpovědi.

c) Jak intenzivně respondenti v díle J. Foglara oceňovali a při četbě proživali „duši otřásajicí spirituální zasvěceni"? Existuje souvislost mezi tím, jaký je jejich vztah $k$ víre (transcendentnu), a tím, jak intenzivně vnímali „spirituální zasvěcení“ v díle J. Foglara?

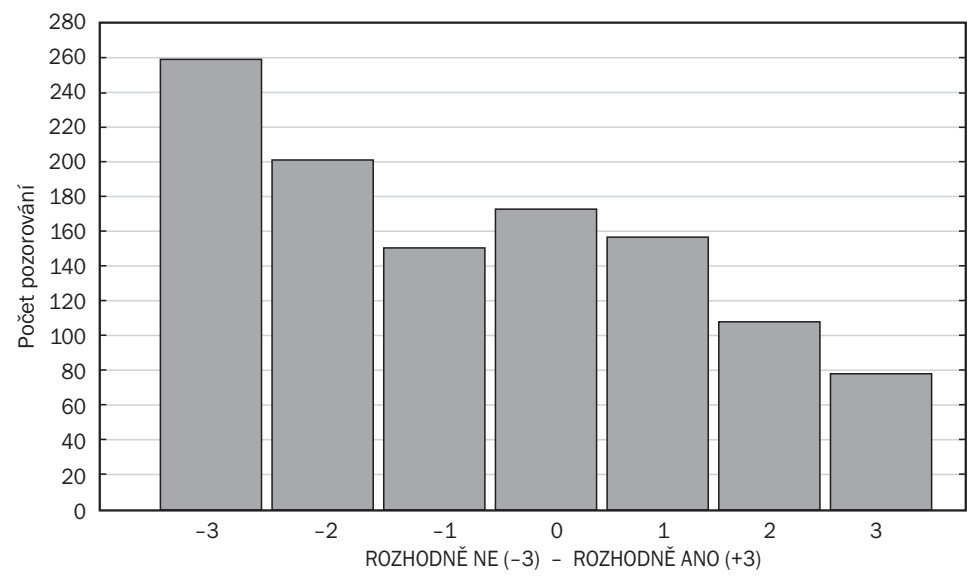

Obr. 4. Histogram - osobní prožitek/ocenění „spirituálního zasvěcení".

Ze sloupcového grafu je patrné, že rozložení odpovědí na jednotlivých škálách je jiné než v předchozím případě (obr. 2). Silně je zastoupeno „,rozhodně ne", a to téměř ve $23 \%$ odpovědí, a společně s ostatními negativními odpověd'mi se blížíme k hranici 54 \%. Naplnění jednotlivých kategorií má sestupnou tendenci, neutrální střed je obdobný a pohybuje se kolem 
$15 \%$. Součet pozitivní identifikace s položkou se pohybuje kolem $30 \%$, což je ve srovnání s předchozím případem o $18 \%$ méně.

Odpovězme nyní na otázku, zda př́íslušenství k určité kategorii religiozity má dopad na způsob vnímání spirituality v díle J. Foglara. Z krabicového grafu je na první pohled pozorovatelné, že respondenti, kteří se hlásí ke spirituální orientaci, zároveň také nejvíce vnímají duchovní dimenzi Foglarova díla. Zajímavostí je, že i respondenti, kteří nemají na náboženství ujasněný názor, se umístují hned na druhém místě, tedy i pro ně je duchovní dimenze díla významná.

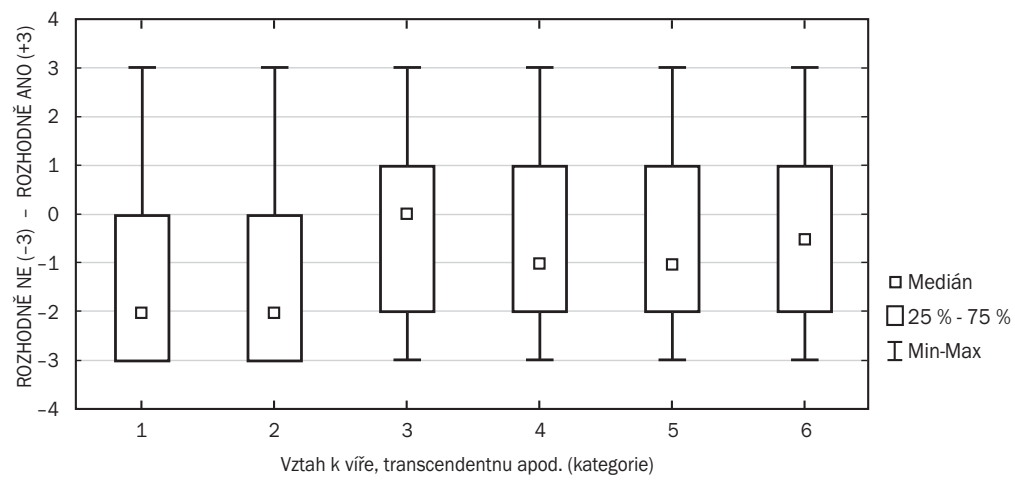

Obr. 5. Krabicový graf dle skupin respondentů a jejich vztahu $\mathrm{k}$ víře - prožitek/ocenění duchovní složky díla.

Legenda ke kategoriím 1-6:

1 - ateismus (bezvěrectví, odmitání boha);

2 - agnosticismus (boha nelze poznat);

3 - spiritualita (duchovní pohled na život a svět);

4 - individualizovaná víra (bez vazby na církve a sekty);

5 - praktikující věricí (hlásící se k definovaným náboženstvím/církvím);

6 - v otázce náboženství nemám ujasněný názor.

Nulovou hypotézu jsme definovali obdobně jako výše: medián zastoupení odpovědí respondentů na škále se $\mathrm{v}$ kontextu jejich vztahu $\mathrm{k}$ víre a transcendentnu nemění, tedy je shodný mezi všemi skupinami. I v tomto př́ipadě se ukázal Kruskal-Wallisův test jako významný na hladině významnosti větší než $\mathrm{p}=0,05$, a proto tuto nulovou hypotézu opět zamítáme ve prospěch alternativní. Příslušnost $\mathrm{k}$ dané kategorii označující vztah $\mathrm{k}$ víře má souvislost $\mathrm{s}$ tím, jak intenzivně respondenti prožívají spirituální dimenzi díla. 
Analogicky formulovanou nulovou hypotézu pro zjištění statistické významnosti rozdílů $v$ odpovědích jednotlivých věkových skupin, tj. že medián zastoupení odpovědí respondentů na škále se podle jejich věku nemění, tedy je shodný mezi všemi věkovými kategoriemi, jsme odmítnout nemohli. Odlišné výsledky nicméně zaznamenáváme u skupiny respondentů ve věku 46-55 let, kteří častěji či ve větší míře oceňovali či prožívali duchovní rozměr díla.

Pokud se na odpovědi respondentů díváme podle toho, jakou formou se s dílem J. Foglara seznámili, zjištujeme vcelku přirozeně, že takové způsoby seznámení jako osobní setkání, odborná reflexe, ale i seznámení skrze metodické příručky či kroniky přinášejí také intenzivnější duchovní prožitek samotného díla. Paradoxně tomu do takové míry není u beletristického literárního zpracování.

d) Aplikuji respondenti některé ze spirituálních hodnot ve svém každodenním životě? Existuje souvislost mezi tím, jaký je jejich vztah $k$ víře (transcendentnu), a tím, zda aplikuji některé ze spirituálních hodnot ve svém životě?

Dostáváme se možná k nejzajímavější otázce našeho výzkumu, která má edukativní a hodnotový rozměr. Skalní behavioristé by řekli, že není až tak důležité, jak hodnoty spojené se spiritualitou prožíváme, ale zda se jimi řídíme v každodenním životě, zda se podle nich chováme. Samožrejmě, že ani v tomto případě nejde o pozitivisticky objektivní a vnější pohled na chování nějakého subjektu, ale o vyjádření míry idiografické subjektivní představy o tom, zda respondenti aplikují spirituální hodnoty pod vlivem díla J. Foglara v každodenním životě. Základní rozmístění odpovědí je opět patrné ze sloupcového grafu (obr. 6).

$\mathrm{Z}$ vizuální komparace je zřejmá analogie s předchozí interpretací. Téměř $54 \%$ respondentů volí možnost v negativní části spektra škály, tedy nemyslí si, že by spirituální hodnoty aplikovali v každodenním životě. $15 \%$ respondentů (identická hodnota jako v předchozím případě) má indiferentní postoj a 29 \% se spíše domnívá, že spirituální hodnoty do svého života přenáší. 


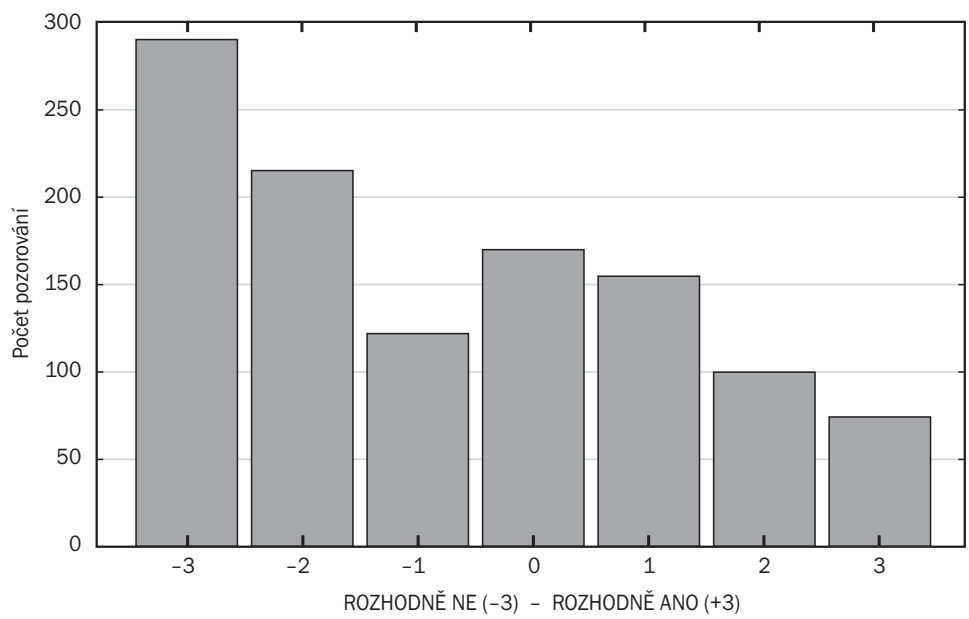

Obr. 6. Histogram - aplikace duchovních hodnot v každodenním životě.

Podívejme se opět, jak se případné uplatňování spirituálních hodnot v každodenním životě odlišuje v kontextu postoje $\mathrm{k}$ religiozitě. Základní odlišnosti opět vypovídajícím způsobem podává krabicový graf (obr. 7).

Stejně jako v př́edchozím případě (obr. 5), kdy bylo pro skupinu respondentů hlásících se ke spiritualitě (v legendě označenou jako kategorie č. 3) dílo důležité z hlediska hodnotového, i v tomto př́ípadě identická skupina uplatňuje spirituální hodnoty v každodenním životě. Na druhém místě se umístila skupina tíhnoucí $\mathrm{k}$ individualizované víře a následně pak praktikující věřící a ti, kteří v otázce náboženství nemají ujasněný názor.

I v tomto př́ípadě jsme realizovali Kruskal-Wallisův test a testovali nulovou hypotézu: medián zastoupení odpovědí respondentů na škále se v kontextu jejich vztahu k víře a transcendentnu nemění, tedy je shodný mezi všemi skupinami. I v tomto případě byl porušen výchozí předpoklad na signifikantní úrovni. Můžeme tedy konstatovat, že vztah k religiozitě souvisí s tím, zda spirituální hodnoty obsažené v díle J. Foglara budou respondenty uplatňovány v každodenním životě, nebo nikoliv. 


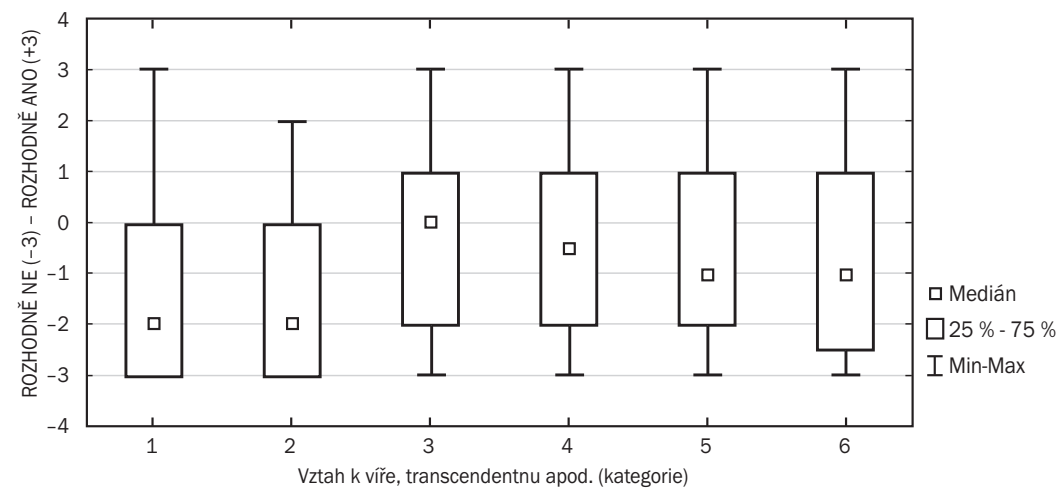

Obr. 7. Krabicový graf dle skupin respondentů a jejich vztahu k víre - reálná aplikace spirituálních hodnot.

Legenda ke kategoriím 1-6:

1 - ateismus (bezvěrectví, odmítání boha);

2 - agnosticismus (boha nelze poznat);

3 - spiritualita (duchovní pohled na život a svět);

4 - individualizovaná víra (bez vazby na církve a sekty);

5 - praktikujicí věricí (hlásicí se k definovaným náboženstvím/církvím);

6 - v otázce náboženství nemám ujasněný názor.

Z hlediska věku se i v tomto případě opakuje situace, kdy respondenti ve věku 46-55 let uvádí na škále větší míru souhlasu s tím, že ve vlastním životě aplikovali spirituální hodnoty, a to v souvislosti s dílem J. Foglara. Stejně se vyjadřují i respondenti, kteří k seznámení s dílem využili forem osobního setkání, reflexe odborné literatury či metodických textů.

\section{Diskuse}

Nejdříve se vyjádříme k několika významným momentům vyplývajícím ze složení výzkumného vzorku, následně budeme interpretovat některá zjišš̌ní, jež vnímáme jako podnětný impuls pro religionistiku.

Prvním podnětem hodným pozornosti je složení výzkumného vzorku z hlediska vzdělání. Hrdiny knih i komiksů J. Foglara jsou především chlapci na konci základní školy či na začátku přípravy na povolání v učilišti nebo průmyslové škole, což mohlo být způsobeno i autorovými vlastními zkušenostmi - vystudoval pouze dvouletou obchodní školu a o hlubší intelektuální či vzdělanostní rozvoj neusiloval. To, stejně jako jeho celoživotní ,,pohyb v myšlenkově nepodnětném prostředí teenagerovských 
klubů“, vedlo ke kritice jeho díla, která jej hodnotila jako „spisky nevalné jazykové a stylistické úrovně, místy různě nedotažené a namnoze s nevěrohodnou fabulí“ ${ }^{29}$ Proto je poměrně překvapivé, že toto dílo oslovuje zejména vysokoškoláky, respektive že právě tato populační kohorta se stala našimi nejvíce zastoupenými respondenty. Přestože nám data neumožňují rozhodnout otázku zdůvodnění (výzva byla šířena veřejně zejména ve foglarovské komunitě, přičemž jediným kritériem byla znalost Foglarova díla, nikoliv věk, dosažené vzdělání či náboženské přesvědčení), zajímavou paralelu můžeme vnímat u skupiny z opačného sociálního pólu společnosti, totiž u vězňů (abychom upřesnili: vzdělání těchto jedinců neznáme, takže se nejedná o přímý protiklad, nicméně využíváme tuto informaci jako ukázku protikladu obvykle vyššího společenského postavení vysokoškolsky vzdělané populace). Jak letmá sonda ilustrovala, ze 180 dotazovaných odsouzených odpovědělo 124 , že vůbec nevědí, kdo je Jaroslav Foglar. Ze zbývajících vědělo 48, že se jedná o spisovatele, 15 uvedlo, že něco četli, avšak pouze 7 (čtyřri starší 40 let, tř́i starší 20 let) dokázalo uvést titul či jmenovat postavy. Nicméně i ti, kteři deklarovali znalost Foglarova díla, v podrobnějších odpovědích ukazovali spíše jeho neznalost (například přisuzovali Foglarovi autorství Broučkủ nebo ho spojovali se Švejkem). ${ }^{30} \mathrm{Z}$ letmého porovnání nemůžeme pochopitelně vyvozovat žádné pevné závěry, nicméně fakt, že zejména vysokoškolsky vzdělaní dospělí znají Foglarovy knihy a pozitivně se vyjadřují k inspiraci, kterou získali v dětství prostřednictvím jejich četby, je bezpochyby pozoruhodný.

Druhou velmi důležitou charakteristikou je věk, v němž se respondenti s touto četbou seznámili. Dětský čtenář, který je tomuto druhu literatury otevřen, si ponechává vstřícný a přivětivý postoj i v dospělosti, zatímco dojde-li $\mathrm{k}$ seznámení až $\mathrm{v}$ dospělém věku, může převažovat odmítnutí $\mathrm{s}$ důrazem na naivitu, nereálnost či schematičnost příběhů. $\mathrm{S}$ ohledem na informace sumarizované v popisu výzkumného souboru můžeme konstatovat, že našimi respondenty jsou zejména dospělí jedinci, u nichž lze předpokládat, že míra jejich životních zkušeností jim umožňuje zdárně se orientovat $\mathrm{v}$ různorodých souvislostech životních úkolů, a to $\mathrm{v}$ kontextu životní naplněnosti či smysluplného prožívání, včetně tematiky spirituality a náboženské víry. Naši respondenti se většinově narodili v mezidobí let 1975-1990, tedy v období, které je na straně jedné ohraničeno vrcholící normalizací, charakteristickou mimo jiné i početnějšími populačními roč-

29 Stanislav Komárek, „Jestřáb a kuřátka“, in: id., Mír s mloky, Brno: Petrov 2003, 105111: 105.

30 Jan Jirásek, „Reflexe tvorby Jaroslava Foglara u odsouzených ve výkonu trestu odnětí svobody“, in: Ivo Jirásek (ed.), Fenomén Foglar, Praha: Prázdninová škola Lipnice 2007, 226-231. 
níky (tzv. Husákovy děti), a na straně druhé závěrem osmdesátých let, kdy docházelo k rozvolňování a erozi socialistického společenství (v daném kontextu například debaty s Jaroslavem Foglarem, počátky opětovného vydávání jeho knížek apod.). Deklarované pozitivní ocenění díla dospělými jedinci, kteří se s ním seznámili v dětství, tak opět potvrzuje odlišnou optiku recepce četby v porovnání s literární kritikou, požadující i po dětské literatuře dodržování nároků vysokého umění.

Jestliže souhrnně jen necelých 39 \% respondentů vyjádřilo negativní či nevyjasněný postoj k otázkám víry, náboženství a spirituality a $61 \%$ dotazovaných deklarovalo jistou podobu pozitivně orientovaného vztahu $\mathrm{k}$ víře, transcendentnu apod., získává tento soubor další výraznou odlišnost od většinové populace. Při prozatím posledním censu (2011) se totiž k náboženské víře (vyznání) přihlásilo zhruba $20,8 \%$ obyvatel, ${ }^{31}$ zatímco dle nedávného šetření dosahuje religiozita českých mladých lidí ve věku 19-26 let dokonce pouhých $9 \% .{ }^{32}$ Náboženská chladnost autora, sekulární obsah díla a čtenáři otevření spirituálním hodnotám, a navíc deklarující, že je nalezli právě v této četbě, tak přináší celou řadu otázek, které by stály za budoucí hlubší prozkoumání. Ani zde (obdobně jako u většinového vysokoškolského vzdělání) však nejsme schopni rozhodnout ve věci př́ičinnosti, nevíme tedy, zda spirituálně založení jedinci vnímají implicitně náboženské prvky Foglarova díla díky svým náboženským zájmům, nebo zda naopak jejich duchovní založení je důsledkem recepce Foglara. Můžeme však zřetelně konstatovat, že i při množství dalších působících vlivů individuálních i společenských je spirituální a implicitně náboženský postoj jedinců, kteří v dětství četli foglarovky, mimořádně vysoký. A co je ještě mnohem důležitější pro kontext tohoto článku, téměř každý druhý čtenář této dětské literatury z našeho vzorku v ní vnímal implicitně náboženskou dimenzi. Empiricky podloženými údaji tak můžeme potvrdit teoreticky již delší dobu známé hermeneutické interpretace, které ve Foglarových textech nalézají archetypy mýtopoetické zkušenosti, jak jsme souhrnně rekapitulovali výše v části věnované religionistickému zájmu o tento druh dobrodružné literatury. Právě v empiricky podloženém a statisticky podaném důkazu teoretických úvah o implicitně náboženském rozměru foglarovek spatřujeme hlavní př́inos tohoto textu pro religionisti$\mathrm{ku}$.

31 Český statistický úřad, „Změny struktury obyvatel podle náboženské víry v letech 1991, 2001 a 2011“ [online], in: Náboženská víra obyvatel podle výsledků sčítání lidu - 2011, <https://www.czso.cz/csu/czso/nabozenska-vira-obyvatel-podle-vysledku-scitani-lidu-2011-61wegp46fl>, [1. 2. 2021].

32 Stephen Bullivant, Europe's Young Adults and Religion: Findings from the European Social Survey (2014-16) to Inform the 2018 Synod of Bishops, Twickenham, UK: Benedict XVI Centre for Religion and Society, St Mary's University 2018, 6. 
Jenom obtížně však můžeme tímto př́íspěvkem vstoupit do mezinárodní diskuse, nebot analýza literárních děl určených dětským čtenářům s důrazem na implicitní náboženství je většinou zaměřena na obsahovou analýzu těchto děl, nikoliv na výzkum čtenářských zkušeností a jejich aplikací do reálného prožívání. Studie Pavla Hoška, dávající do souvislostí texty J. Foglara a literaturu Lewise a Tolkiena, ${ }^{33}$ zajímavě koresponduje s analýzou Howarda Worsleyho, odkrývající u stejných autorů téma křestanské milosti, identifikované $\mathrm{v}$ dětské literatuře $\mathrm{s}$ bezpodmínečnou láskou, vnímanou zejména jako odpuštění a absence pomsty. ${ }^{34}$ Další souvislosti jsou však již vzdálenější a vazba na naše téma se ukáže spíše u tematiky spirituality a dětské literatury. S ohledem na vymezení implicitního náboženství v Baileyho pojetí však můžeme takovou pomyslnou vazbu akceptovat a pak se téma vyjevuje jako mnohem více zastoupené, a to v rozmanitých souvislostech. Rozvoj spirituality u dětí je obvykle traktován v rozeznávání duchovní dimenze ve vztahu k sobě (reflexe, smysl, údiv a úžas), druhým lidem (láska, spravedlnost), přírodě (environmentální citlivost) a transcendenci (s různou variabilitou od explicitní religiozity vyjádřené vztahem $\mathrm{k}$ bohu až $\mathrm{k}$ významným životním okamžikům, jako je narození nebo smrt). ${ }^{35}$ Obdobné strukturaci odpovídají i dílčí rozbory sledující dětskou literaturu např́klad z pohledu smrti, ${ }^{36}$ tematiky genderu, ${ }^{37}$ klimatických změn ${ }^{38}$ či dětských představ o božství. ${ }^{39}$ Domníváme se, že témata vnímaná při četbě foglarovek (duchovní inspirace, mýtus, rituál, zážitek něčeho velkého, „otřes duše“), dosvědčená takřka polovinou našich re-

33 P. Hošek, Evangelium podle Jaroslava Foglara...

34 Worsley ovšem nezohledňuje Foglara a navíc reflektuje Rowlingovou. Howard Worsley, „Children's Literature as Implicit Religion: The Concept of Grace Unpacked“, Implicit Religion 13/2, 2010, 161-171.

35 Brendan Hyde, ,The Identification of Four Characteristics of Children's Spirituality in Australian Catholic Primary Schools“, International Journal of Children's Spirituality 13/2, 2008, 117-127; Jennifer Mata-McMahon - Michale J. Haslip - Deborah L. Schein, „Early Childhood Educators' Perceptions of Nurturing Spirituality in Secular Settings“, Early Child Development and Care 189/14, 2019, 2233-2251; Jack Miller - Susan Drake, ,Toward a Spiritual Curriculum“, Curriculum Inquiry 27/2, 1997, 239245; Geoff Rogers - Doug Hill, „Initial Primary Teacher Education Students and Spirituality“, International Journal of Children's Spirituality 7/3, 2002, 273-289.

36 Charles A. Corr, „Spirituality in Death-Related Literature for Children“, Omega: Journal of Death and Dying 48/4, 2003, 365-381.

37 Ann M. Trousdale, ,Intersections of Spirituality, Religion and Gender in Children's Literature“, International Journal of Children's Spirituality 10/1, 2005, 61-79.

38 Anna Chitando, „African Children's Literature, Spirituality, and Climate Change“, Ecumenical Review 69/3, 2017, 375-385.

39 Catherine R. Posey, „Unexpected Illuminations: How Children's Perceptions of the Divine Are Highlighted through Their Discussion of Two Toy Fantasy Novels“, International Journal of Children's Spirituality 18/2, 2012, 135-147. 
spondentů, doplňují zmíněné propojení spirituality a dětské literatury o nové významové odstíny.

Poslední moment, k němuž bychom se rádi diskusně vyjádřili, se týká překvapení, kterého se nám během analýzy dat opakovaně dostávalo, totiž nevýrazných výsledků skupiny praktikujících věřících mezi našimi respondenty (zejména u prožitku z četby vnímaného jako „otřes duše“ a u aplikace spirituálních hodnot $\mathrm{v}$ životě). Na základě sociodemografických podmínek můžeme předpokládat, že většina těchto jedinců, kteří se charakterizovali jako praktikující věřící hlásící se k definovaným náboženstvím či církvím, je římskokatolického vyznání. Nemůžeme vyloučit, že jednou z př́íčin tohoto slabého duchovního ovlivnění zprostředkovaného četbou foglarovek může být pevně vyprofilovaná a bytostně proživaná religiozita, zakotvená v jasně definovaných a ustálených literárních předlohách daného náboženství (Bible nebo Katechismus katolické církve), stejně jako v hodnotově zřetelné dikci oficiálních dokumentů (papežské encykliky apod.). Pak bychom mohli předpokládat, že tato specifická populace našeho výzkumu nečerpá své duchovní inspirace z jiných než křestanských zdrojů. Spirituální podněty či zážitky může hledat v četbě beletrie křestanských autorů (Léon Bloy, Gilbert Keith Chesterton, Guy Gilbert apod.), nikoliv však u civilně a záměrně sekulárně píšícího Foglara, byt by popisoval téměř shodné prŕiběhové zápletky s obdobným ponaučením. K rozvoji pevně vyprofilované křestanské spirituality tak může posloužit dětská četba nejenom implicitně, ale zejména explicitně náboženská, od Komenského díla Orbis pictus ${ }^{40}$ až po moderní obrázkové i textové knihy určené dětem. ${ }^{41}$

\section{Závěrem}

$\mathrm{V}$ příspěvku jsme se zaměřili na implicitně náboženskou složku Foglarova díla, přičemž je pochopitelné a všeobecně srozumitelné, že mnohé jiné aspekty této literatury, její četby a z ní pramenících prožitků, včetně aplikace v reálném životě, se v získaných datech vyznačují mnohem vyšší hodnotou i preferencí. Táboření, pobyt v přírodě, hry a další programy, akcentace zdravého životního stylu a mravného chování, stejně jako

40 Andrew Spicer, „Religious Representation in Comenius's Orbis sensualium pictus (1658)“, Reformation and Renaissance Review 21/1, 2019, 64-88.

41 Burhanettin Keskin, „On Harold's ,Translucent Reality“: A Philosophical and Religious Interpretation of Harold and the Purple Crayon", Early Child Development and Care 187/8, 2019, 1349-1358; Ann Trousdale, „Honouring the Questions: Shifts in the Treatment of Religion in Children's Literature“, International Journal of Children's Spirituality 16/3, 2011, 219-232; Susan Stan, „Religious Topics in Children's Literature“, Word and World 15/1, 1995, 91-97. 
pedagogická inspirace obecně jsou Foglarem výslovně tematizovány a v textech jsou patrné zcela zjevně. Implicitně náboženské aspekty chlapeckých románů lze vysuzovat a detekovat spíše v druhém plánu, za obsahy a použitými termíny, v sémantické rovině významů a hodnot, jež je v povrchní četbě spíše skryta. Přesto jsou pro podstatnou skupinu čtenářù tyto rysy četby srozumitelné a obohacující.

Můžeme tedy naším výzkumem pokládat za prokázané, že tato literatura (autorem zamýšlená jako výchovná inspirace chlapců) přináší čtenářům i další hlubší životní rozměry. Úvahy primárně vedené diskursem literární vědy a historie a doplněné poznáním religionistiky, které poukazují na spirituální a náboženské souvislosti tohoto svébytného literárního korpusu, ${ }^{42}$ tak můžeme podepřít empirickým dokladem. $Z$ výpovědí našich respondentů lze zcela přesvědčivě podepřít závěr, že nejvýraznější je tento rozměr foglarovek pro jedince se spirituální orientací a pro ty, kteří na náboženství nemají ujasněný názor, a patří tedy spíše mezi hledající. Spisovatel a skautský vychovatel Jaroslav Foglar opakovaně deklaroval svoji náboženskou skepsi, patrnou např́iklad v dlouhodobé korespondenci s českobratrským evangelickým farářem. ${ }^{43}$ Navzdory tomu se jeho přímá vychovatelská činnost stala některým oddílovým svěřencům motivem pro misionářský život ${ }^{44}$ a někteři jej později kontaktovali s tím, že právě jeho výchova a knihy se staly jedním z hybných momentů při přerodu mravních zásad v náboženský život $\mathrm{v}$ rámci společenství Svědkové Jehovovi. ${ }^{45}$ Autorova náboženská netečnost a lhostejnost, vtělená i do spisů, však svými hlubšími rozměry za slovy samotnými rezonuje s imaginálním světem archetypů za všedností každodenního obstarávání. Naše empirické šetření podtrhuje, že působící síla tohoto zakotvení je mnohem razantnější, než by mohla naznačit pouhá obsahová či narativní analýza chlapeckých příběhů. Implicitně náboženská dimenze Foglarova díla je dosvědčena reálnou čtenářskou zkušeností jedinců s rozmanitým náboženským postojem, a to od ateistů až po praktikující věřící.

42 M. Dvorský, Mýtus zvaný Stínadla...; P. Hošek, Evangelium podle Jaroslava Foglara...; I. Jirásek, „Rychlé šípy, ,mundus imaginalis“...“, T. Vučka, Cesta za modrým světlem...

43 Petr Vyleta, „Milý pane faráři!“, Sborník nezávislých foglarovců 2, 2010, 18-23.

44 Otto Janka, Bernard od Šleného koně, Praha: Ostrov 2002.

45 M. Dvorský, Mýtus zvaný Stínadla... 


\section{SUMMARY}

\section{Implicitly Religious Aspects of Children's Literature by Jaroslav Foglar}

The hugely popular author of children's literature Jaroslav Foglar wrote stories about boys on the threshold of adolescence undergoing a personality transformation under the influence of a positive example of friendship and an active lifestyle. However, the themes of honesty, of health and physical activity, and of living in natural surroundings cannot alone justify why this fiction is also viewed from the perspective of the science of religion using terms such as "cult", "mystery", "evangelistic text", "initiation", "functional equivalent of religion", or "implicit religion". Empirical research within the framework of a larger questionnaire survey therefore addresses the question of whether the readers of these books are recruited from backgrounds that are religious, spiritual, or indifferent, whether they are aware of this literature for children having a certain spiritual component, and whether they perceive it as a way of realizing spiritual experience. The group of respondents in the research ( $\mathrm{n}=1135$, of whom 666 were men and 464 women) were most often in the 30-55-year-old age group, with a university degree, living in a larger city with more than 100,000 inhabitants, and with diverse relationships to religious faith and spirituality. According to the results, we found that this literature offered some form of spiritual inspiration to $48 \%$ of the respondents, that $30 \%$ of the respondents perceived this spiritual component intensely, and that $29 \%$ believed that they had applied some of the spiritual values associated with the books in their daily lives. The theoretical interest of religious studies in this literature for boys is thus empirically justified.

Keywords: scouting; spirituality; reading; implicit religion; Jaroslav Foglar.

Faculty of Physical Culture

IVO JIRÁSEK

Palacký University Olomouc

Tř. Míru 115

ivo.jirasek@upol.cz

77111 Olomouc

Czech Republic

Faculty of Education

JIŘí NĚMEC

Masaryk University

Poříčí 623/7

nemec@ped.muni.cz

60300 Brno

Czech Republic

Faculty of Education

University of South Bohemia in České Budějovice

Dukelská 9

37115 České Budějovice

RICHARD MACKU゚

Czech Republic 